\title{
Comparative Analysis of Volatile Organic Compounds in Class II and Metro Cities in Maharashtra, India
}

\author{
E. Ravendiran ${ }^{1}$, S.C. Kollur ${ }^{1}$, V.M. Motghare ${ }^{1}$, Ajay R. Ojha ${ }^{2}$, \\ Prasad R. Pawar ${ }^{2}$ and Swanandi Sathaye ${ }^{2}$
}
${ }^{1}$ Maharashtra Pollution Control Board, Kalpataru Point, Sion, Mumbai 400 022, India
${ }^{2}$ Technogreen Environmental Solutions, Wakadewadi, Pune 411 003, India

*Corresponding author

\section{A B S T R A C T}

\section{Keywords \\ VOC, BTX, Diurnal \\ variability, Seasonal \\ variability, Metro \\ cities, Solar \\ radiation, Benzene, \\ Toluene, $\mathrm{m}$, p- \\ xyelene, Online \\ monitoring \\ Article Info \\ Accepted: \\ 15 April 2019 \\ Available Online: \\ 10 May 2019}

\begin{abstract}
Increasing concentrations of volatile organic compounds (VOCs) is a matter of significant concern with respect to the long term impacts on human health and environment. While transport is the greatest contributor of VOCs in ambient air, other sources such as industries and petrol pumps also contribute significantly. The study and analysis of VOCs is important to identify emission sources and impacts. Samples of ambient air were collected and analyzed at three locations in the cities of Mumbai, Nagpur and Pune using an online VOC72M Analyzer. A study was carried out to analyze concentrations of benzene, toluene and $\mathrm{m}$, p- xylene in these cities in order to create a comparative account of diurnal and seasonal variability of these compounds. The results show 1.Annual concentration ranges: $0.35 \mu \mathrm{g} / \mathrm{m}^{3}$ (minimum) to 24.73 $\mu \mathrm{g} / \mathrm{m}^{3}$ (maximum); 2. Correlation between cities - the minimum concentration was found in Pune while the maximum concentration was found in Nagpur. 3. In general, levels of BTX were higher during summer and winter and were inversely proportional to sunlight.
\end{abstract}

\section{Introduction}

Volatile organic compounds (VOCs) are released into the environment through both nonmoving and mobile sources (Somet a., 2007). In urban outdoor environments, Combustion of fuel for energy production and vehicular transport are major contributors of VOCs (Hinwood, 2007; Kampa and Castanas, 2008; Srivastava, 2005). In the urban atmosphere, VOCs have toxic effects on humans and can potentially carcinogenicity and mutagenicity in exposed individuals (Srivastava, 2005). Humans also get exposed to VOCs through indoor air pollution. The health effects of VOCs include irritation and allergies of the eyes, nose, throat and skin, loss of coordination, headaches, nausea, fatigue, and conjunctival irritation, while also causing damage to the kidneys, liver and central nervous system (Srivastava, Joseph and Devotta, 2006; Rumchev, Broan and Spickett, 2007). However, probably the most significant health risk of exposure to outdoor 
VOC pollution is asthma and chronic bronchitis in adults as well as children (Mølhave, 1991). Information on temporal and seasonal variability inurban areas of Indian cities is not abundant and therefore a need for research in this area is felt.

Among the wide spectrum of VOCs, benzene, toluene, ethyl benzene and meta $(\mathrm{m})$ and para (p) xylene (BTEX) are the most widely studied compounds (Som et al., 2007; Maisey et al., 2013; Miri et a., 2016). Benzene is classified as a Group I human carcinogen by the International Agency for Research on Cancer, while toluene and m-p- xylenes affect the respiratory and nervous systems (Gaur, Singh and Shukla, 2016). It is due to the multitude of sources for these compounds and the spectrum of health effects that VOCs are required to be monitored in urban atmospheres. This report gives a comparative account of concentrations of BTX in ambient air in three metropolitan cities in India, in the State of Maharashtra, namely, Mumbai, Nagpur and Pune. Diurnal and seasonal variability of these compounds has been analyzed.

\section{Study area}

Analysis of concentrations of BTX recorded at sampling locations situated in three metropolitan cities in Maharashtra, viz. Mumbai, Nagpur and Pune was carried out. Mumbai is a cosmopolitan metropolis and the capital of Maharashtra and is located on the west coast of the Indian subcontinent. Being a rapidly developing metropolis, Mumbai is a hub for technological, industrial, commercial, and port activity.

The most recent census of 2011 records the population of Mumbai at 1.84 billion while the vehicle population as of January, 2017 was about 3 million. The climate of Mumbai can be described as tropical wet and dry with average annual temperature of $27^{\circ} \mathrm{C}$ and average annual rainfall of $2422 \mathrm{~mm}$.

Nagpur is the winter capital of Maharashtra and the third largest city in the State. It is predicted to be the $5^{\text {th }}$ fastest growing city in the world from 2019 to 2035 with an average growth of $8.41 \%$. It also marks the geographical center of India. The average annual temperature of Nagpur is $26^{\circ} \mathrm{C}$ and the average annual rainfall that the city receives is $1092 \mathrm{~mm}$. The climate of Nagpur is tropical.

The third location where VOCs were monitored was Pune. Pune is located on the western part of the Deccan Plateau at an altitude of $560 \mathrm{~m}$ above sea level. The city is widely known for its educational research institutes as well as institutes for information technology, management and training which attract students and professionals from all over India and overseas. The climate of Pune can be described as hot and semi-arid bordering on tropical wet and dry. The average annual temperatures are in the range of $20^{\circ} \mathrm{C}$ to $28^{\circ} \mathrm{C}$. The average annual rainfall is $722 \mathrm{~mm}$.

\section{Sampling locations}

India has 573 locations for air monitoring under the National Air Monitoring Program (NAMP) (ENVIS, 2019), of which 73 are installed in the State of Maharashtra. However most of these monitoring stations are manually operated as per NAAQS (CPCB). Recently, Maharashtra has incorporated 9 online monitoring stations which include VOCs analysis in ambient air (CPCB). There is currently one sampling location in each of the three cities as shown in Figure 1. These sampling and monitoring stations have been established and are operated by the Maharashtra Pollution Control Board (MPCB) under Continuous Ambient Air Quality Monitoring Stations. 
The sampling station at Mumbai is located adjacent to the Western Express Highway in Bandra East. The sampling station at Nagpur is located in a residential area between Rajrani Chowk and Civil Lines. In Pune, the sampling station is located at Cummins College of Engineering near Karve Road. The coordinates of these locations are provided in Table 1. Locations for monitoring ambient air quality stations are selected in keeping with the Guidelines for Planning the Sampling of Atmosphere determined by Bureau of Indian Standards (2000) as well as the Guidelines for Ambient Air Quality Monitoring by Central Pollution Control Board and Ministry of Environment and Forests (2003). The location of the monitoring stations is representative of the area selected and the ambient conditions.

\section{Materials and Methods}

Sampling of ambient air for analysis of BTX was carried out using an online VOC72M Analyzer at all three locations. The operation of this analyzer is based on separation of measured compounds by gas chromatography and detection using photo-ionization. The analyzer measures up to 40 VOCs including benzene, toluene, ethyl benzene, $\mathrm{m}$, $\mathrm{p}$ - xylene, o-xylene and 1-3 butadiene. The low detection limit of the analyzer is $\leq 0.05 \mu \mathrm{g} / \mathrm{m}^{3}$ benzene and the sample flow is $50 \mathrm{ml}$ per minute. Trap sampling, cold purge, injection, hot purge and trap cooling are the five steps of the analysis cycle.

\section{Results and Discussion}

\section{Ambient concentrations}

The sampling locations in the cities of Mumbai, Nagpur and Thane are situated not more than $2 \mathrm{~km}$ from major highways. In Mumbai the sampling location is situated about $50 \mathrm{~m}$ from the Western Express Highway, while at Nagpur the sampling location is about 550m from the NagpurAurangabad Highway. In Pune, the sampling location is situated $1.9 \mathrm{~km}$ from the Asian Highway 47. However, it is located only about 350m from Karve Road, a busy major road in the city. Standards for VOCs in India, except benzene in ambient air, are absent and hence information regarding ambient concentrations, environmental impacts and effects on human health is still restricted. The annual standard for benzene in ambient air as defined by the Central Pollution Control Board in its notification dated $18^{\text {th }}$ November, 2009 is $5 \mu \mathrm{g} / \mathrm{m}^{3}$. The concentrations of BTX recorded during summer are the averages of concentrations recorded in the months of January, February, March and April. The concentrations recorded for monsoon are the averages of concentrations recorded during the months of May, June, July and August. The averages of concentrations recorded during September, October, November and December are the concentrations reported during winter. Table 2 presents the seasonal and annual averages of total BTX recorded at Mumbai, Nagpur and Pune.

In general, only the average annual concentration of benzene recorded at Nagpur exceeds the annual standard for benzene in ambient set by the CPCB. Benzene concentrations at Mumbai and Pune are observed to be within the standard limit. As standards for toluene and xylene are not provided for India, seasonal and annual concentrations of these two compounds cannot be studied at present in terms of their exceedance and apparent environmental and health effects.

\section{Diurnal variation of benzene, toluene and xylene in Mumbai, Nagpur and Pune}

The trend in mean benzene concentrations in Mumbai, Nagpur and Pune show a general increasing trend during summer months after 
which the concentrations decrease gradually till monsoon. The concentrations increase during winter months. This trend is depicted in Figures 2, 3 and 4. In all the three cities the benzene concentrations show a slight increase during the month of July. The concentrations of benzene in the cities of Mumbai, Nagpur and Pune have been analyzed with respect to the monthly mean of solar radiation to study diurnal variation. From the figures, it is evident that benzene concentrations are inversely proportional to solar radiation. In winter months, when the average sunlight is recorded to be lower, benzene concentrations are seen to be on a rise, while during summer when the solar radiation is high, the BTX concentrations show a declining trend. During monsoon, while solar radiation shows a drop, the BTX concentrations can be found to have slightly increased. Table 3 shows details of the monthly means of benzene concentrations and solar radiation recorded per hour per day during the year 2018 .

In Mumbai, the concentration of benzene was found to be highest during the month of November and lowest during August, while in Nagpur, the month of January had the highest mean benzene concentration and the lowest concentration was found during August. In Pune, the highest benzene concentration can be observed during January and the lowest concentration was found between June and September. Table 4 shows the shows details of the monthly means of toluene concentrations and solar radiation recorded per hour per day during the year 2018 .

It is evident from Table 4 that the highest concentration of toluene at Mumbai, Nagpur and Pune was observed during January and the lowest concentration at Mumbai was found during May and August. The lowest toluene concentration at Nagpur was found during August. In Pune the lowest concentration of toluene was recorded during
June and August. Table 5 shows the shows details of the monthly mean of toluene concentrations and solar radiation recorded per hour per day during the year 2018 .

Table 5 shows that the highest concentration of xylene at Mumbai and Pune was recorded during January 2018. The lowest concentration of xylene at Mumbai was recorded in the month of July. The lowest xylene levels at Pune were recorded between the months of June and September. At Nagpur, the highest concentration of xylene was recorded in December while the lowest concentration was recorded during August.

\section{City-wise variation of trends of BTX}

The trends of BTX for the year 2018 show a 'W' shaped trend where the concentrations of BTX were high during the beginning of the year, lowest during the middle of the year and high during the end of the year followed by a marked decrease again after November. The annual trends of BTX in respective cities during the year 2018 are represented graphically in Figure 5, 6 and 7.

\section{Mumbai}

At Mumbai, the concentrations of BTX were high during January and decreases over the months of February to May. During May, the concentrations were low while a slight increase was seen during June and July. The BTX levels decreased again during August, followed by a steep rise over the months of September to November. During December the levels were found to have decreased. Table 6 shows the average monthly concentrations of BTX recorded at Mumbai for the year 2018 .

From the table it can be observed that the highest concentration of BTX was recorded during November and the lowest 
concentration was recorded during August. The highest level of toluene was observed during the month of January while the lowest concentration was recorded during the months of May and August. The highest concentration of xylene was recorded during the month of January and lowest level was observed during the month of July.

\section{Nagpur}

In the city of Nagpur the BTX concentrations show a trend similar to that in Mumbai. The concentrations are highest during the summer and winter months and lowest during monsoon. The annual trends of BTX in the city of Nagpur during the year 2018 are represented graphically in Figure 6.

In the city of Nagpur the BTX concentration was high during January and steadily declined till July when there was a slight increase or plateau in the trend. This was followed by a fall in concentrations in the month of August after which the levels increased till November. During December, only the concentration of toluene decreased. Benzene concentration was steady during November and December while xylene concentrations increased in December. Table 7 shows the average monthly concentrations of BTX recorded at Nagpur for the year 2018.

Table 7 shows that the highest levels of benzene and toluene were found during January and the lowest concentrations were found during July. The highest concentrations of xylene were found during the month of
December while the lowest levels were found during August.

\section{Pune}

Concentrations of BTX in Pune show an extended period of decrease during the summer and monsoon months thereby showing a slight deviation from the trends of BTX concentrations observed in the cities of Mumbai and Nagpur. However, the general trend of increased concentrations toward the beginning and end of the year is similar to the trends seen in Mumbai and Nagpur. The annual trends of BTX in the city of Pune during the year 2018 are represented graphically in Figure 7.

BTX concentrations were high during January and decreased till April. A sudden increase in BTX levels was observed during May, although not has high as concentrations recorded in January. The months of June, July, August and September saw very low levels of BTX followed by increased concentrations till December. Table 8 shows the average monthly concentrations of BTX recorded at Pune for the year 2018.

It is evident from Table 8 that the highest concentrations of benzene, toluene and xylene in Pune were found in the month of January. The lowest concentrations of benzene and xylene were recorded between June and September. The lowest toluene concentration was recorded during the months of June and August.

Table.1 Locations of online VOC monitoring stations

\begin{tabular}{|c|c|c|}
\hline Location & Latitude & Longitude \\
\hline Bandra, Mumbai & $19^{\circ} 03^{\prime} 41.8^{\prime \prime} \mathrm{N}$ & $72^{\circ} 50^{\prime} 46.0^{\prime \prime} \mathrm{E}$ \\
\hline Nagpur CAAQMS & $21^{\circ} 09^{\prime} 03.61^{\prime \prime N}$ & $79^{\circ} 04^{\prime} 06.00^{\prime \prime} \mathrm{E}$ \\
\hline Karve Road CAAQMS, Pune & $18^{\circ} 30^{\prime} 40.21^{\prime \prime N}$ & $73^{\circ} 50^{\prime} 28.56^{\prime \prime} \mathrm{E}$ \\
\hline
\end{tabular}


Table.2 Seasonal variation of BTX observed at Mumbai, Nagpur and Pune

\begin{tabular}{|c|c|c|c|c|c|}
\hline BTX & & Summer & Monsoon & Winter & Annual \\
\hline \multirow{2}{*}{$\begin{array}{c}\text { Benzene } \\
\left(\boldsymbol{\mu g} / \mathbf{m}^{\mathbf{3}}\right)\end{array}$} & Mumbai & 1.279 & 0.466 & 1.683 & 1.142 \\
\cline { 2 - 6 } & Nagpur & 7.970 & 2.988 & 5.624 & 5.527 \\
\cline { 2 - 7 } & Pune & 0.112 & 0.035 & 0.090 & 0.079 \\
\hline \multirow{2}{*}{ Toluene $\left(\boldsymbol{\mu g} / \mathbf{m}^{\mathbf{3}}\right)$} & Mumbai & 5.246 & 0.796 & 4.664 & 3.568 \\
\cline { 2 - 7 } & Nagpur & 28.341 & 18.000 & 27.860 & 24.734 \\
\cline { 2 - 7 } & Pune & 1.031 & 0.356 & 0.926 & 0.771 \\
\hline \multirow{2}{*}{ Xylene $\left(\boldsymbol{\mu g} / \mathbf{m}^{\mathbf{3}}\right)$} & Mumbai & 1.696 & & & 1.190 \\
& Nagpur & 17.387 & 7.352 & 22.034 & 15.591 \\
\hline & Pune & 0.517 & 0.112 & 0.421 & 0.350 \\
\hline
\end{tabular}

Table.3 Monthly means of benzene concentrations and mean solar radiation during 2018

\begin{tabular}{|c|c|c|c|c|}
\hline \multirow{2}{*}{ Month } & \multicolumn{3}{|c|}{ Mean Benzene $\left(\boldsymbol{\mu g} / \mathbf{m}^{\mathbf{3}}\right)$} & \multirow{2}{*}{$\begin{array}{c}\text { Mean Solar } \\
\text { Radiation }\left(\mathbf{W} / \mathbf{m}^{\mathbf{2}}\right)\end{array}$} \\
\cline { 2 - 5 } & Mumbai & Nagpur & Pune & 73.01 \\
\hline January & 2.08 & 10.27 & 0.20 & 109.41 \\
\hline February & 1.69 & 8.42 & 0.14 & 130.52 \\
\hline March & 0.95 & 7.16 & 0.07 & 166.05 \\
\hline April & 0.40 & 6.03 & 0.04 & 168.99 \\
\hline May & 0.40 & 3.88 & 0.09 & 160.37 \\
\hline June & 0.53 & 2.85 & 0.02 & 95.94 \\
\hline July & 0.56 & 3.16 & 0.02 & 95.94 \\
\hline Sugust & 0.37 & 2.06 & 0.02 & 139.26 \\
\hline Octember & 0.88 & 3.43 & 0.02 & 131.26 \\
\hline November & 1.53 & 7.20 & 0.06 & 98.10 \\
\hline December & 2.60 & 9.80 & 0.11 & 106.99 \\
\hline
\end{tabular}

Table.4 Monthly means of toluene concentrations and mean solar radiation during 2018

\begin{tabular}{|c|c|c|c|c|}
\hline \multirow{2}{*}{ Month } & \multicolumn{3}{|c|}{ Mean Toluene $\left(\boldsymbol{\mu g} / \mathbf{m}^{\mathbf{3}}\right)$} & $\begin{array}{c}\text { Mean Solar } \\
\text { Radiation }\left(\mathbf{W} / \mathbf{m}^{\mathbf{2}}\right)\end{array}$ \\
\cline { 2 - 5 } & Mumbai & Nagpur & Pune & 73.01 \\
\hline January & 9.07 & 34.04 & 1.75 & 109.41 \\
\hline February & 7.01 & 29.20 & 1.33 & 130.52 \\
\hline March & 3.45 & 25.26 & 0.66 & 166.05 \\
\hline April & 1.46 & 24.87 & 0.38 & 168.99 \\
\hline May & 0.60 & 17.63 & 0.79 & 160.37 \\
\hline June & 1.15 & 14.41 & 0.20 & 95.94 \\
\hline July & 0.83 & 15.09 & 0.24 & 95.94 \\
\hline August & 0.60 & 9.70 & 0.20 & 139.26 \\
\hline September & 2.40 & 19.81 & 0.24 & 131.26 \\
\hline October & 4.29 & 28.51 & 0.68 & 98.10 \\
\hline November & 6.80 & 34.02 & 1.20 & 106.99 \\
\hline December & 5.17 & 29.10 & 1.59 & \\
\hline
\end{tabular}


Table.5 Monthly means of xylene concentrations and mean solar radiation during 2018

\begin{tabular}{|c|c|c|c|c|}
\hline \multirow{2}{*}{ Month } & \multicolumn{3}{|c|}{ Mean Xylene $\left(\boldsymbol{\mu g} / \mathbf{m}^{\mathbf{3}}\right)$} & $\begin{array}{c}\text { Mean Solar } \\
\text { Radiation }\left(\mathbf{W} / \mathbf{m}^{2}\right)\end{array}$ \\
\cline { 2 - 5 } & Mumbai & Nagpur & Pune & 73.01 \\
\hline January & 2.87 & 22.84 & 0.98 & 109.41 \\
\hline February & 2.01 & 17.99 & 0.69 & 130.52 \\
\hline March & 1.01 & 14.91 & 0.29 & 168.95 \\
\hline April & 0.90 & 13.80 & 0.11 & 160.37 \\
\hline May & 0.28 & 9.31 & 0.21 & 95.94 \\
\hline June & 0.40 & 8.09 & 0.08 & 95.94 \\
\hline July & 0.27 & 6.92 & 0.08 & 139.26 \\
\hline August & 0.28 & 5.09 & 0.08 & 131.26 \\
\hline September & 0.73 & 10.93 & 0.08 & 98.10 \\
\hline October & 1.53 & 20.83 & 0.27 & 106.99 \\
\hline November & 2.17 & 27.26 & 0.56 & \\
\hline December & 1.84 & 29.11 & 0.78 & \\
\hline
\end{tabular}

Table.6 Average monthly concentrations of BTX in Mumbai

\begin{tabular}{|c|c|c|c|}
\hline Month & Benzene $\left(\boldsymbol{\mu g} / \mathbf{m}^{\mathbf{3}}\right)$ & Toluene $\left(\boldsymbol{\mu g} / \mathbf{m}^{\mathbf{3}}\right)$ & Xylene $\left(\boldsymbol{\mu g} / \mathbf{m}^{\mathbf{3}}\right)$ \\
\hline January & 2.08 & 9.07 & 2.87 \\
\hline February & 1.69 & 7.01 & 2.01 \\
\hline March & 0.95 & 3.45 & 1.01 \\
\hline April & 0.40 & 1.46 & 0.90 \\
\hline May & 0.40 & 0.60 & 0.28 \\
\hline June & 0.53 & 1.15 & 0.40 \\
\hline July & 0.56 & 0.83 & 0.27 \\
\hline August & 0.37 & 0.60 & 0.28 \\
\hline September & 0.88 & 2.40 & 0.73 \\
\hline October & 1.53 & 4.29 & 1.53 \\
\hline November & 2.60 & 6.80 & 2.17 \\
\hline December & 1.72 & 5.17 & 1.84 \\
\hline
\end{tabular}

Table.7 Average monthly concentrations of BTX in Nagpur

\begin{tabular}{|c|c|c|c|}
\hline Month & Benzene $\left(\boldsymbol{\mu g} / \mathbf{m}^{\mathbf{3}}\right)$ & Toluene $\left(\boldsymbol{\mu g} / \mathbf{m}^{\mathbf{3}}\right)$ & Xylene $\left(\boldsymbol{\mu g} \mathbf{g} \mathbf{m}^{\mathbf{3}}\right)$ \\
\hline January & 10.27 & 34.04 & 22.84 \\
\hline February & 8.42 & 29.20 & 17.99 \\
\hline March & 7.16 & 25.26 & 14.91 \\
\hline April & 6.03 & 24.87 & 13.80 \\
\hline May & 3.88 & 17.63 & 9.31 \\
\hline June & 2.85 & 14.41 & 8.09 \\
\hline July & 3.16 & 15.09 & 6.92 \\
\hline August & 2.06 & 9.70 & 5.09 \\
\hline September & 3.43 & 19.81 & 10.93 \\
\hline October & 7.20 & 28.51 & 20.83 \\
\hline November & 9.80 & 34.02 & 27.26 \\
\hline December & 9.89 & 29.10 & 29.11 \\
\hline
\end{tabular}


Table.8 Average monthly concentrations of BTX in Pune

\begin{tabular}{|c|c|c|c|}
\hline Month & Benzene $\left(\boldsymbol{\mu g} / \mathbf{m}^{\mathbf{3}}\right)$ & Toluene $\left(\boldsymbol{\mu} \mathbf{g} / \mathbf{m}^{\mathbf{3}}\right)$ & Xylene $\left(\boldsymbol{\mu g} \mathbf{g} \mathbf{m}^{\mathbf{3}}\right)$ \\
\hline January & 0.20 & 1.75 & 0.98 \\
\hline February & 0.14 & 1.33 & 0.69 \\
\hline March & 0.07 & 0.66 & 0.29 \\
\hline April & 0.04 & 0.38 & 0.11 \\
\hline May & 0.09 & 0.79 & 0.21 \\
\hline June & 0.02 & 0.20 & 0.08 \\
\hline July & 0.02 & 0.24 & 0.08 \\
\hline August & 0.02 & 0.20 & 0.08 \\
\hline September & 0.02 & 0.24 & 0.08 \\
\hline October & 0.06 & 0.68 & 0.27 \\
\hline November & 0.11 & 1.20 & 0.56 \\
\hline December & 0.16 & 1.59 & 0.78 \\
\hline
\end{tabular}

Table.9 Seasonal variation in inter-species ratios of BTX in Mumbai, Nagpur and Pune

\begin{tabular}{|c|c|c|c|}
\hline \multicolumn{4}{|c|}{ Mumbai } \\
\hline & Summer & Monsoon & Winter \\
\hline T/B & 4.102 & 1.708 & 2.772 \\
\hline $\mathbf{X y} / \mathbf{B}$ & 1.326 & 0.659 & 0.932 \\
\hline \multicolumn{4}{|c|}{ Nagpur } \\
\hline T/B & 3.556 & 6.024 & 4.954 \\
\hline $\mathbf{X y} / \mathbf{B}$ & 2.181 & 2.460 & 3.918 \\
\hline \multicolumn{4}{|c|}{ Pune } \\
\hline T/B & 9.203 & 10.115 & 10.328 \\
\hline$X \mathbf{X} / \mathbf{B}$ & 4.618 & 3.194 & 4.698 \\
\hline
\end{tabular}

Fig.1 Google maps image of Maharashtra showing three locations of VOC monitoring.

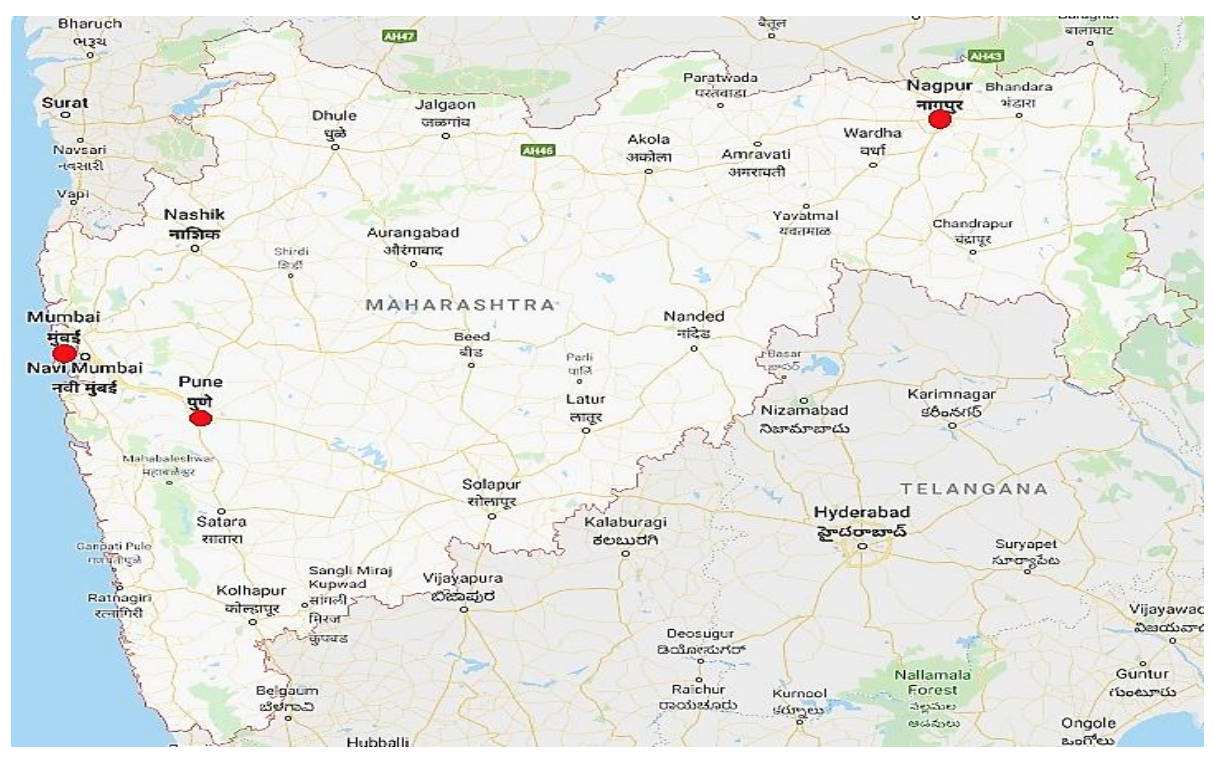


Fig.2 Annual trend in mean benzene concentrations in the cities of Mumbai, Nagpur and Pune during the year 2018

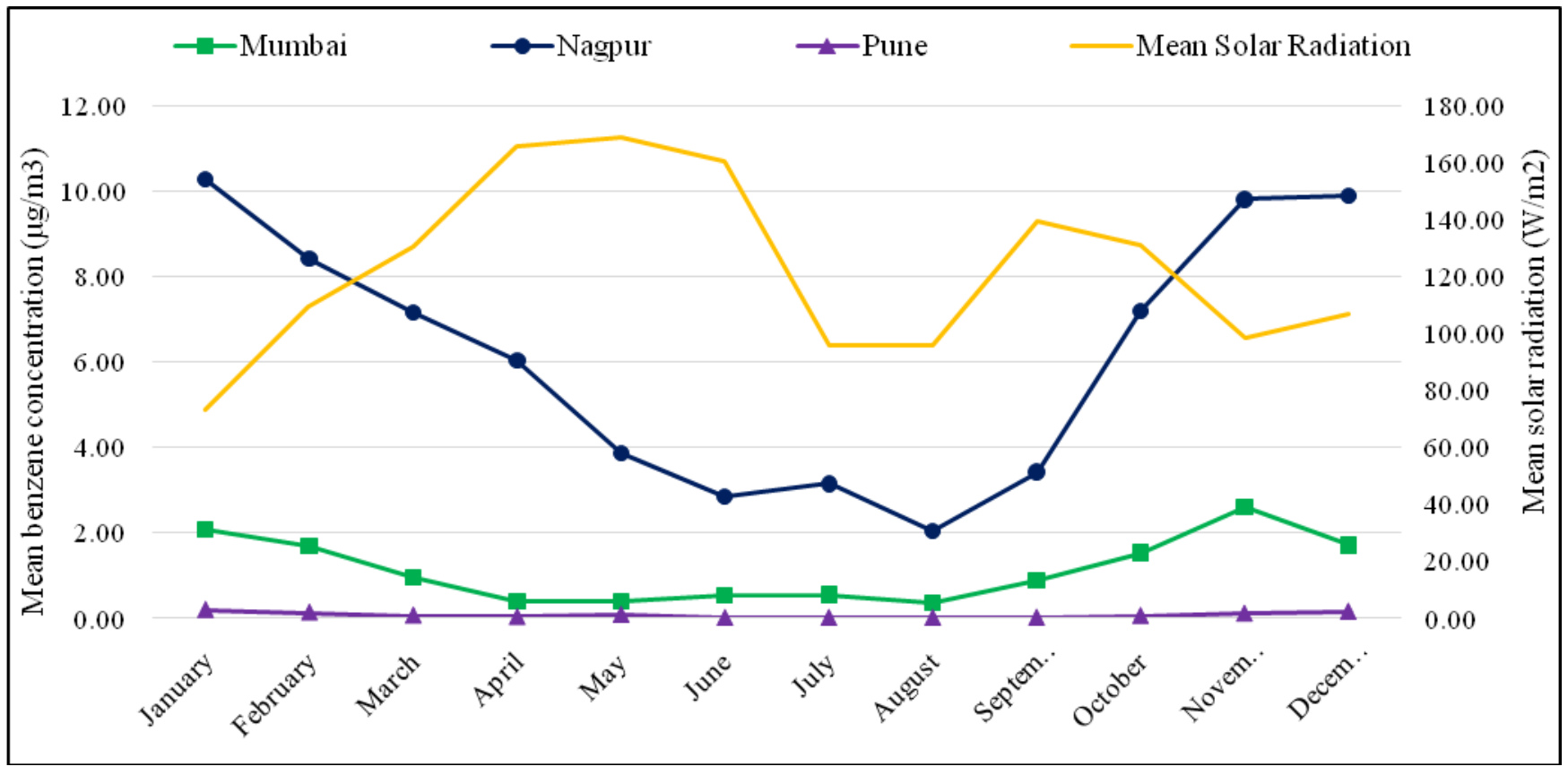

Fig.3 Annual trend in mean Toluene concentrations in the cities of Mumbai, Nagpur and Pune during the year 2018

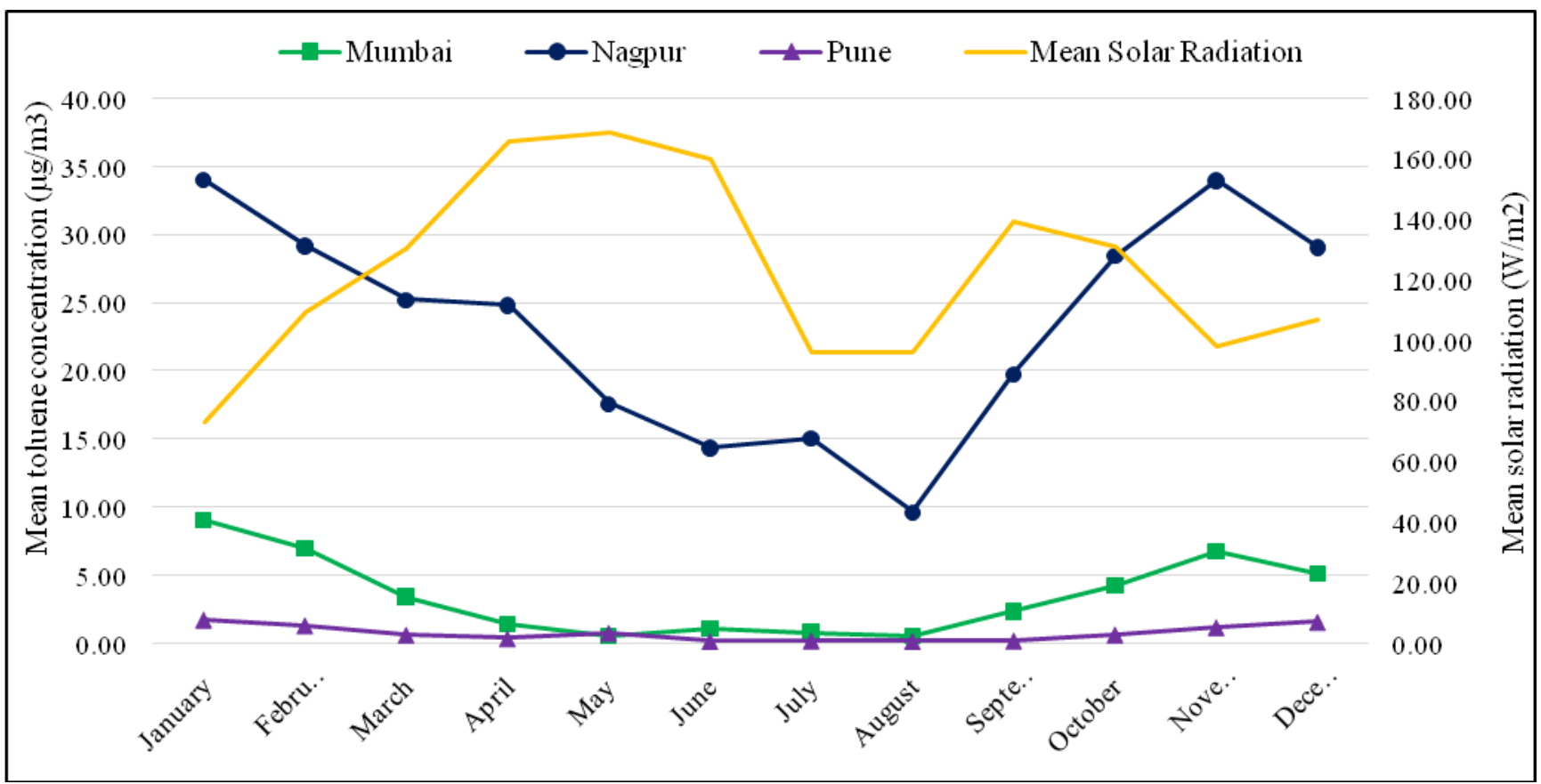


Fig.4 Annual trend in mean Xylene concentrations in the cities of Mumbai, Nagpur and Pune during the year 2018

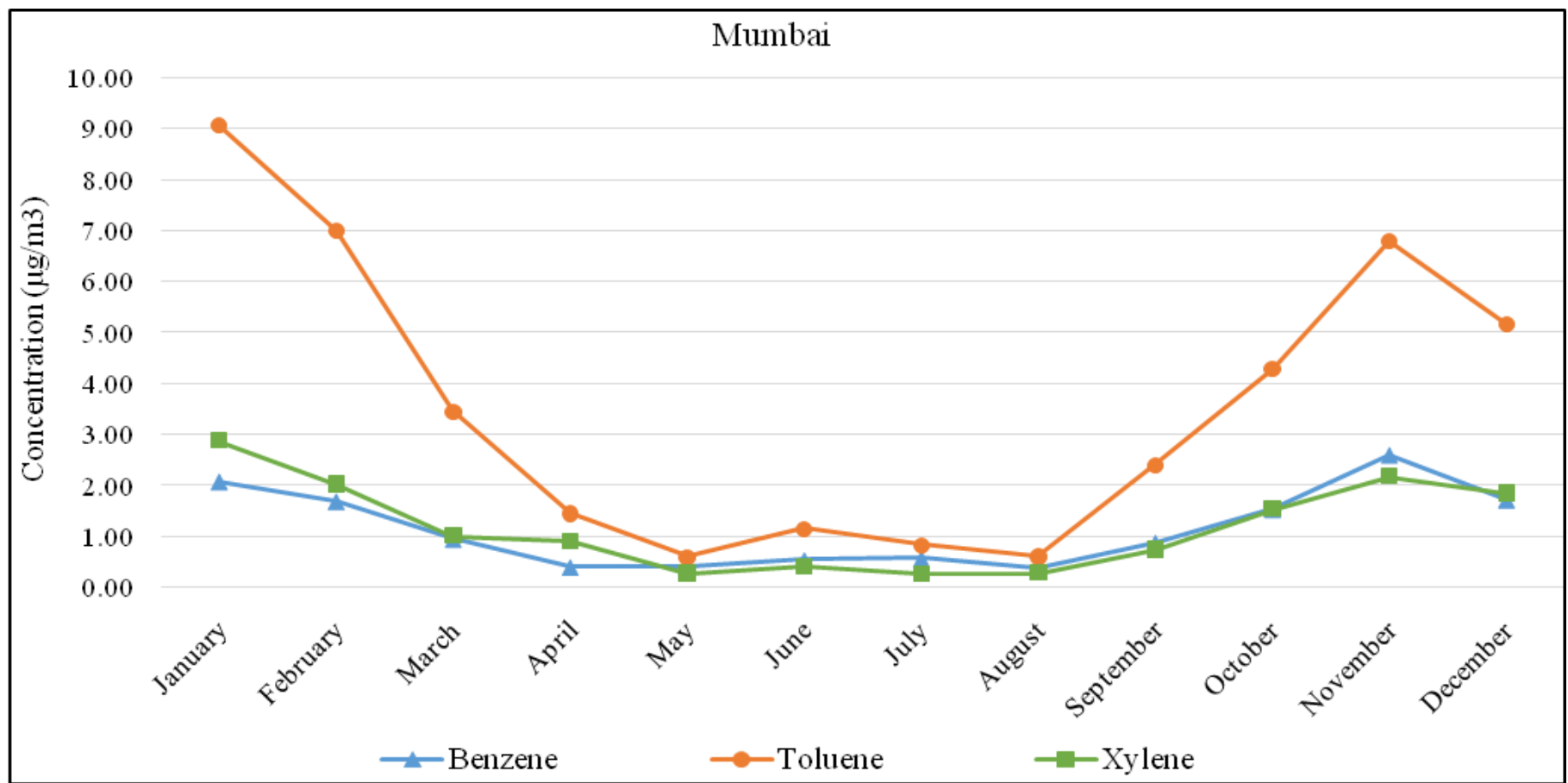

Fig.5 Annual trend of BTX in Mumbai

(Mumbai


Fig.6 Annual trend of BTX in Nagpur

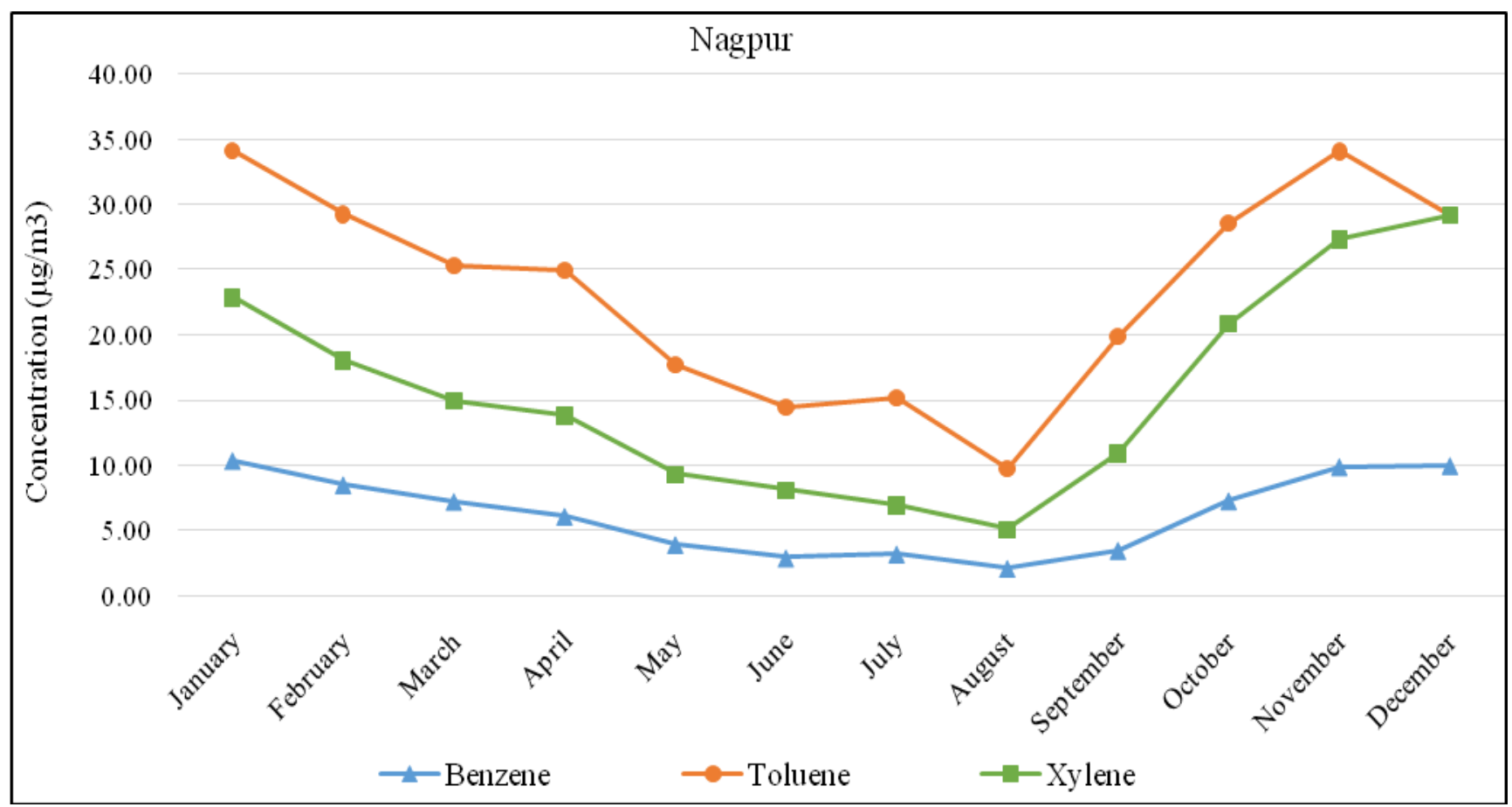

Fig.7 Annual trend of BTX in Pune

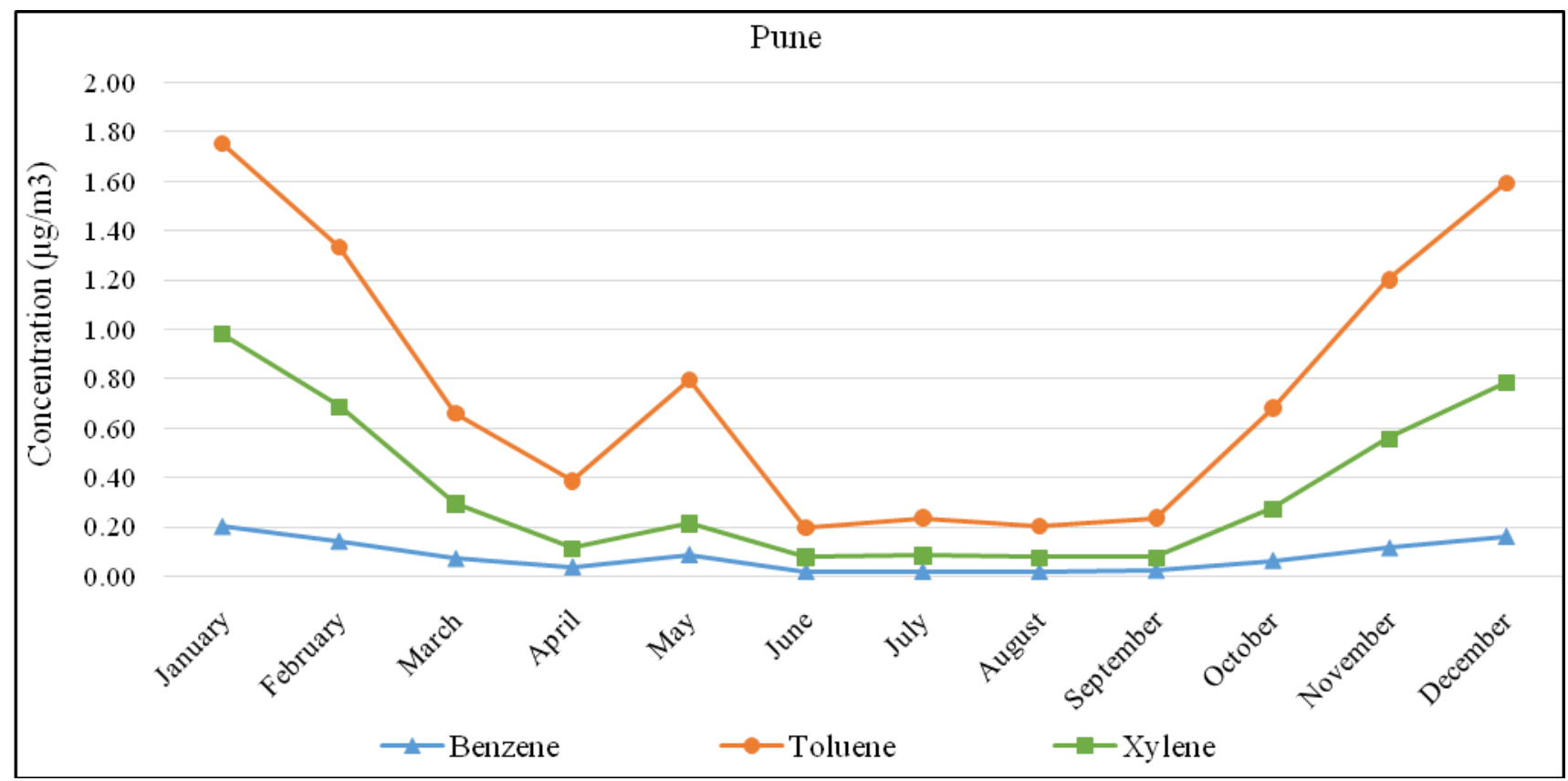

Urban areas which are densely populated are sites of generation of BTEX from anthropogenic activities Cerón-Bretón et al., 2015). The compounds included in the BTEX class of VOCs are highly carcinogenic, mutagenic and genotoxic (Alghamdi et al., 2014). These compounds play a critical role in atmospheric chemistry on account of their 
active participation in photochemical reactions (Alghamdi et al., 2014; CerónBretón et al., 2015; Miri et al., 2016). The typical lifetimes of BTEX compounds in the atmosphere are relatively short with respect to the atmospheric removal of BTEX facilitated by the reaction where the $\mathrm{OH}$ radical is removed. Considering this reaction, the lifetime of benzene is 225 hours, that of toluene is 50 hours and that of xylenes is 12 to 19 hours (12 hours for m-xylene; 15 hours for p-xylene) (Alghamdi et al., 2014).

The present study includes only benzene, toluene and xylenes for analysis. Results of the study show the inverse relation between BTX and solar radiation in three cities namely Mumbai, Nagpur and Pune. In all three cities, toluene was found to be most abundant with an average concentration of $3.57 \mu \mathrm{g} / \mathrm{m}^{3}$ in Mumbai, $24.73 \mu \mathrm{g} / \mathrm{m}^{3}$ in Nagpur and $0.77 \mu \mathrm{g} / \mathrm{m}^{3}$ in Pune. This was followed by xylenes with an average concentration of $1.19 \mu \mathrm{g} / \mathrm{m}^{3}$ in Mumbai, $15.59 \mu \mathrm{g} / \mathrm{m}^{3}$ in Nagpur and $0.35 \mu \mathrm{g} / \mathrm{m}^{3}$ in Pune. Toluene has been found to be the most abundant compound in several studies carried out in urban environments in countries such as Mexico, Spain and Iran (Parra et al., 2009; Rad et al., 2014; Cerón-Bretón, et al., 2015).

\section{BTX ratios}

Ratios of toluene to benzene and m,p-xylene to benzene are important to ascertain sources of BTX as well as the variations in distances to the emission sources. Table 9 shows the summary of seasonal variation of ratios of toluene to benzene (T/B) and xylenes to benzene $(\mathrm{Xy} / \mathrm{B})$ observed in Mumbai, Nagpur and Pune during the year 2018. These ratios also provide an insight on the sampling locations and are greatly influenced by the climate of the study area, types of sources and lifetime or age of the compounds and air parcels (Alghamdi et al., 2014; Gaur, Singh and Shukla, 2016).

\section{Toluene: Benzene}

\section{Mumbai}

The highest ratio of the annual concentration of toluene to benzene was observed during summer (4.102) followed by winter (2.772). The lowest ration was recorded during monsoon (1.708). A toluene to benzene ratio within the range of 1.5 and 4.3 indicates traffic and transportation as the source of emissions (Alghamdi et al., 2014). Other sources may also include industrial emissions and petrol pumps (Gaur, Singh and Shukla, 2016).

\section{Nagpur}

In Nagpur, the highest ratio of the annual concentration of toluene to benzene was observed during monsoon (6.024) followed by winter (4.954). The lowest ratio was recorded during summer (3.556). An increase of this ratio beyond the typical values may indicate low rainfall which allows for more evaporation of BTX from local industrial areas, petrol pumps, transportation and service stations. The high ratio may also indicate emissions from decomposition of solid waste on dumping lands. Ratios observed during summer and winter are also to the higher limit of the typical range, which may be explained by the increased contribution of photochemical reactions occurring during daytime.

\section{Pune}

The highest toluene to benzene ratio was observed during winter (10.328), followed by monsoon (10.115), followed by summer (9.203). The ratios during all seasons are outside the typical toluene to benzene ratio range. This may indicate higher average temperatures as well as higher incident solar radiations throughout the year and other sources along with traffic emissions to have 
contributed to concentrations of BTX. These sources may include construction activities, increased vehicular count and petrol pumps.

\section{Xylenes: Benzene}

\section{Mumbai}

The highest xylenes to benzene ratio was observed during summer (1.326) followed by winter (0.932) and monsoon (0.659). Xylenes to benzene ratios greater than 1.61 indicate higher degradation through photochemical reactions thereby suggesting that the location of the source is at some distance from the sampling point (Miller et al., 2011). The high ratio seen during summer followed by winter indicates degradation of xylenes by photochemical reactions occurring on account of higher annual incident solar radiation.

\section{Nagpur}

The highest ratio was observed during winter (3.918) followed by monsoon (2.460) and summer (2.181). These ratios are greater than the typical value of 1.61. These high ratios therefore indicate higher photochemical degradation throughout the year as well as lesser proximity of sources from the sampling location.

\section{Pune}

The highest xylenes to benzene was observed during winter (4.698) followed by summer (4.618) and monsoon (3.194). These ratios too are significantly greater than the typical value of 1.61 as described by (Miller et a., 2011). These ratios indicate higher photochemical degradation in the presence of higher average solar radiation throughout the year, although slightly greater during winter and summer. The ratios also suggest that the sources of emissions are located at some distance from the sampling point.
It is concluded in the present study, characterization of concentrations of benzene, toluene and xylenes recorded at the cities of Mumbai, Nagpur and Pune was undertaken. Toluene was found to be present in abundance followed by benzene and xylenes in all the three cities. The results of this study showed a definite seasonal and diurnal variability in the concentrations of BTX in ambient air. The results also showed a distinct inverse relation between concentrations of BTX and solar radiation.

T/B ratios were generally higher in summer and winter in Mumbai and Pune. A greater T/B ratio was observed during monsoon in Nagpur which may suggest availability of higher sunshine for photochemical reactions and degradation due to the arid environment. Generally high $\mathrm{Xy} / \mathrm{B}$ ratios also indicate a greater occurrence of photochemical degradation. These results suggest probable sources of BTX as well as the distance of sources from sampling locations. For a comprehensive analysis and comparison of BTX and VOCs in general across sources, more sampling stations are required to be installed at known and possible sources of VOCs which include petrol pumps, industrial clusters and traffic congestion junctions. It will also be an interesting study to estimate the contribution of the Chandrapur Super Thermal Power Station to the current levels of VOCs in Nagpur.

Also, the absence of standards for VOCs other than benzene in ambient air for India is of great concern as it is difficult to determine the extent of impacts of VOC concentrations on the environment as well as on humans. Establishment of these standards will be instrumental in improving quality of fuels as well has vehicle technology and will also facilitate the improvement of emission regulations. 


\section{Acknowledgment}

Technogreen Environmental Solutions expresses its gratitude to the Hon'ble Member Secretary of the MPCB for agreeing to collaborate with the project and for his valuable support, and Mr. S. C. Kollur (Scientific Officer, MPCB) for providing valuable timely inputs and extensive data.

\section{References}

Alghamdi, M.A., Khoder, M., Abdelmaksoud, A.S., Harrison, R.M., Hussein, T., Lihavainen, H., Al-Jeelani, H., Goknil, M.H., Shabbaj, I.I., Almehmadi, F.M. and Hyvärinen, A.P. (2014). Seasonal and diurnal variations of BTEX and their potential for ozone formation in the urban background atmosphere of the coastal city Jeddah, Saudi Arabia. Air Quality, Atmosphere \& Health, 7(4): 467-480.

Bureau of Indian Standards (2000). Methods for measurement of air pollution. Part 14 Guidelines for planning the sampling of atmosphere.

Central Pollution Control Board and Ministry of Environment \& Forests (2003). Guidelines for ambient air quality monitoring.

Cerón-Bretón, J.G., Cerón-Bretón, R.M., Kahl, J.D.W., Ramírez-Lara, E., Guarnaccia, C., Aguilar-Ucán, C.A., Montalvo-Romero, C., AnguebesFranseschi, F. and López-Chuken, U. (2015). Diurnal and seasonal variation of BTEX in the air of Monterrey, Mexico: preliminary study of sources and photochemical ozone pollution. Air Quality, Atmosphere \& Health, 8(5): 469-482.

ENVIS, CPCB, Delhi, India (2019). Air Pollution: National Air Quality Monitoring Programme (NAMP) [ONLINE] Available at: http://cpcbenvis.nic.in/airpollution/mon etoring.htm. [Accessed 18 April 2019].

Gaur, M., Singh, R. and Shukla, A. (2016). Variability in the levels of BTEX at a pollution hotspot in New Delhi, India. Journal of Environmental Protection, 7(10): 1245-1258.

Hinwood, A.L., Rodriguez, C., Runnion, T., Farrar, D., Murray, F., Horton, A., Glass, D., Sheppeard, V., Edwards, J.W., Denison, L. and Whitworth, T. (2007). Risk factors for increased BTEX exposure in four Australian cities. Chemosphere, 66(3): 533-541.

Kampa, M. and Castanas, E. (2008). Human health effects of air pollution. Environmental pollution, 151(2): 362367.

Maisey, S.J., Saunders, S.M., West, N. and Franklin, P.J. (2013). An extended baseline examination of indoor VOCs in a city of low ambient pollution: Perth, Western Australia. Atmospheric environment, 81: 546-553.

Miller, L., Xu, X., Wheeler, A., Atari, D.O., Grgicak-Mannion, A. and Luginaah, I. (2011). Spatial variability and application of ratios between BTEX in two Canadian cities. The Scientific World Journal, 11: 2536-2549.

Miri, M., Shendi, M.R.A., Ghaffari, H.R., Aval, H.E., Ahmadi, E., Taban, E., Gholizadeh, A., Aval, M.Y., Mohammadi, A. and Azari, A. (2016). Investigation of outdoor BTEX: concentration, variations, sources, spatial distribution, and risk assessment. Chemosphere, 163: 601-609.

Mølhave, L. (1991). Volatile organic compounds, indoor air quality and health. Indoor Air, 1(4): 357-376.

Parra, M.A., Elustondo, D., Bermejo, R. and Santamaria, J.M. (2009). Ambient air levels of volatile organic compounds (VOC) and nitrogen dioxide (NO2) in a medium size city in Northern Spain. 
Science of the Total Environment, 407(3): 999-1009.

Rad, H.D., Babaei, A.A., Goudarzi, G., Angali, K.A., Ramezani, Z. and Mohammadi, M.M. (2014). Levels and sources of BTEX in ambient air of Ahvaz metropolitan city. Air Quality, Atmosphere \& Health, 7(4): 515-524.

Rumchev, K., Brown, H. and Spickett, J. (2007). Volatile organic compounds: do they present a risk to our health? Reviews on environmental health, 22(1): 39-56.

Srivastava, A., 2005. Variability in VOC concentrations in an urban area of
Delhi. Environmental monitoring and assessment, 107(1-3): 363-373.

Srivastava, A., Joseph, A.E. and Devotta, S., 2006. Volatile organic compounds in ambient air of Mumbai-India. Atmospheric Environment, 40(5): 892903.

Som, D., Dutta, C., Chatterjee, A., Mallick, D., Jana, T.K. and Sen, S. (2007). Studies on commuters' exposure to BTEX in passenger cars in Kolkata, India. Science of the Total Environment, 372(2-3): 426-432.

\section{How to cite this article:}

Ravendiran, E., S.C. Kollur, V.M. Motghare, Ajay R. Ojha, Prasad R. Pawar and Swanandi Sathaye. 2019. Comparative Analysis of Volatile Organic Compounds in Class II and Metro Cities in Maharashtra, India. Int.J.Curr.Microbiol.App.Sci. 8(05): 1900-1914. doi: https://doi.org/10.20546/ijcmas.2019.805.220 